Correspondence

Peter F. Dunfield dunfield@staff.uni-marburg.de

\title{
Methylocella silvestris sp. nov., a novel methanotroph isolated from an acidic forest cambisol
}

\author{
Peter F. Dunfield, ${ }^{1}$ Valentina N. Khmelenina, ${ }^{2}$ Natalia E. Suzina, ${ }^{2}$ \\ Yuri A. Trotsenko ${ }^{2}$ and Svetlana N. Dedysh ${ }^{3}$ \\ ${ }^{1}$ Max-Planck-Institut für terrestrische Mikrobiologie, D-35043 Marburg, Germany \\ ${ }^{2}$ Institute of Biochemistry and Physiology of Microorganisms, Russian Academy of Sciences, \\ Pushchino, Moscow Region 142292, Russia \\ ${ }^{3}$ Institute of Microbiology, Russian Academy of Sciences, Moscow 117811, Russia
}

\begin{abstract}
Two strains of Gram-negative, aerobic, non-pigmented, non-motile, rod-shaped, methane-oxidizing bacteria were isolated from an acidic forest cambisol near Marburg, Germany, and were designated as strains $B L 2{ }^{\top}$ and $A 1$. These bacteria were morphologically and phenotypically similar to Methylocella palustris $\mathrm{K}^{\top}$. The cells possess a highly specific bipolar appearance. They lack the intracytoplasmic membranes common to all methane-oxidizing bacteria except Methylocella, but contain a vesicular membrane system connected to the cytoplasmic membrane. A soluble methane monooxygenase was present, but no particulate methane monooxygenase could be detected. These bacteria utilize the serine pathway for carbon assimilation. Strains $B L 2{ }^{\top}$ and $A 1$ are moderately acidophilic, mesophilic organisms capable of growth at $\mathrm{pH}$ values between 4.5 and 7 (with an optimum at $\mathrm{pH} 5.5$ ) and at temperatures between 4 and $30^{\circ} \mathrm{C}$. Compared with Methylocella palustris $\mathrm{K}^{\top}$, these strains have greater tolerance of cold temperatures, dissolved salts and methanol. On the basis of $16 \mathrm{~S}$ rRNA gene sequence identity, of species with validly published names, strain $\mathrm{BL} 2^{\top}$ is most closely related to Methylocella palustris $\mathrm{K}^{\top}$ ( $97 \cdot 3 \%$ identity), Beijerinckia indica subsp. indica ATCC $9039^{\top}(97 \cdot 1 \%)$ and Methylocapsa acidiphila B2 ${ }^{\top}$ $(96 \cdot 2 \%)$. The DNA G $+C$ content is 60 mol\% and the major phospholipid fatty acid is $18: 1 \omega 7$. Strain BL2 ${ }^{\top}$ showed only 21-22 \% DNA-DNA hybridization with Methylocella palustris $\mathrm{K}^{\top}$. The data therefore suggest that strains $B 2^{\top}$ and $\mathrm{A} 1$ represent a novel species of Methylocella; the name Methylocella silvestris sp. nov. is proposed, with strain $\mathrm{BL}^{\top}{ }^{\top}\left(=\mathrm{DSM} 15510^{\top}=\mathrm{NCIMB}\right.$ $13906^{\top}$ ) as the type strain.
\end{abstract}

\section{INTRODUCTION}

Aerobic methanotrophic bacteria are able to use methane $\left(\mathrm{CH}_{4}\right)$ as a sole carbon and energy source. The 11 currently recognized genera of methanotrophs belong to the $\gamma$ - and $\alpha$-subclasses of the Proteobacteria; these are respectively designated as type I or type II methanotrophs. The two types differ physiologically in several ways, most notably in their carbon-assimilation pathways [ribulose monophosphate

Published online ahead of print on 13 January 2003 as DOI 10.1099/ ijs.0.02481-0.

Abbreviations: DNMS, dilute nitrate mineral salts; ICM, intracytoplasmic membrane; pMMO, particulate methane monooxygenase; sMMO, soluble methane monooxygenase.

The GenBank/EMBL/DDBJ accession numbers for the 16S rRNA gene sequence and the partial gene sequences of mmoX, mxaF and nifH of Methylocella silvestris strain BL2 ${ }^{\top}$ are respectively AJ491847AJ491850.
(RuMP) versus serine pathway] and the arrangement of intracytoplasmic membranes (ICMs) (Hanson \& Hanson, 1996).

The existence of methanotrophs adapted to high or low extremes of temperature, $\mathrm{pH}$ and salinity has been demonstrated by cultivation-independent molecular ecology techniques and by the isolation and characterization of pure cultures (Murrell et al., 1998; Trotsenko \& Khmelenina, 2002). Much of the Earth's surface, including most wetlands and forest soils of the temperate and boreal zones, is acidic. Recently, novel acidophilic methanotrophs were isolated from Sphagnum peat bogs and described as the new genera and species Methylocella palustris (Dedysh et al., 1998, 2000) and Methylocapsa acidiphila (Dedysh et al., 2002). These isolates grow optimally at about $\mathrm{pH} 5 \cdot 5$. They belong to the $\alpha$-subclass of the Proteobacteria but do not form a monophyletic group with the previously known type II methanotrophs of the genera Methylosinus and Methylocystis. 
Instead, they are closely related to the acidophilic, nonmethanotrophic bacterium Beijerinckia indica. Methylocapsa acidiphila $\mathrm{B} 2^{\mathrm{T}}$, like most other known methanotrophs, possesses the particulate methane monooxygenase enzyme (pMMO) and contains a well-developed ICM system in which pMMO is bound. Methylocella palustris does not contain an ICM system, which makes it unique among methanotrophs. The genes encoding the pMMO enzyme, which are present in all other methanotrophs, could not be detected in Methylocella palustris with either a PCR assay considered universal for the $p m o A$ gene or hybridization with a $p m o A$ gene fragment of Methylococcus capsulatus Bath. Methylocella palustris, therefore, appears to possess a soluble form of methane monooxygenase (sMMO) only.

Here, we describe a third organism belonging to this acidophilic group of methanotrophs. This organism was isolated from acidic forest soil rather than from Sphagnum peat.

\section{METHODS}

Isolation and maintenance of strains $\mathrm{BL2}^{\mathbf{T}}$ and $\mathbf{A} 1$. Soil cores in plastic tubes $(3 \mathrm{~cm}$ diameter, $13 \mathrm{~cm}$ depth) were sampled in

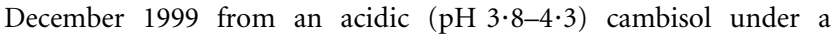
beech-dominated forest stand near Marburg, Germany. Details of the soil, its methane-oxidation rate and the methanotrophic community detectable with molecular methods were published previously (Henckel et al., 2000). Intact cores were sealed at the bottom and placed in a gas-tight chamber containing $20 \%(\mathrm{v} / \mathrm{v}) \mathrm{CH}_{4}$ in air. The headspace in the chamber was replaced periodically.

After 6 months, soil crumbs from the mineral A horizon $(8-13 \mathrm{~cm}$ from the soil surface) of the cores were sprinkled on plates of dilute nitrate mineral salts (DNMS) medium. This was nitrate mineral salts medium, as described previously for the isolation of methanotrophic bacteria (Hanson et al., 1991), diluted 1:5 with distilled water and containing $1 \mathrm{mM} \mathrm{NaH} \mathrm{PO}_{4} / \mathrm{Na}_{2} \mathrm{HPO}_{4}$ buffer ( $\mathrm{pH} \mathrm{5} \cdot 8$ ). DNMS was solidified with Bacto agar ( $15 \mathrm{~g} \mathrm{l}^{-1}$; Difco). After incubation for 2 months in an atmosphere containing $20 \% \mathrm{CH}_{4}$, slimy, semitransparent masses developed around most soil crumbs on the plates. These were carefully picked with a loop and restreaked onto fresh DNMS plates. Single colonies were successively selected from plates for restreaking until pure cultures were obtained. Two such cultures were designated $\mathrm{BL} 2^{\mathrm{T}}$ and $\mathrm{A} 1$.

Reference bacterial strains. Methylocella palustris $\mathrm{K}^{\mathrm{T}}$ (=ATCC $\left.700799^{\mathrm{T}}\right)$, Methylocapsa acidiphila $\mathrm{B}^{\mathrm{T}}\left(=\mathrm{DSM} 13967^{\mathrm{T}}=\mathrm{NCIMB}\right.$ $13765^{\mathrm{T}}$ ) and B. indica subsp. indica ATCC $9039^{\mathrm{T}}$ were used as reference strains. Methylocapsa acidiphila $\mathrm{B}^{\mathrm{T}}$ was grown on half-strength nitrogen-free M1 medium (Dedysh et al., 2002). Methylocella palustris $\mathrm{K}^{\mathrm{T}}$ was cultivated on M1 medium supplemented with $250 \mathrm{mg}$ $\mathrm{KNO}_{3} 1^{-1}$ and solidified with $1 \cdot 5 \%(\mathrm{w} / \mathrm{v})$ agar. Both methanotrophs were grown under a gas phase of $10 \%(\mathrm{v} / \mathrm{v}) \mathrm{CH}_{4}$ in air. $\mathrm{B}$. indica subsp. indica ATCC $9039^{\mathrm{T}}$ was grown on nitrogen-free mineral medium containing glucose (Becking, 1984).

Verification of strain purity. Culture purity was ensured by examination under phase-contrast and electron microscopy and by plating on media containing the following different organic substrates: nutrient agar (Difco), nutrient agar diluted 1:10 or DNMS supplemented with either $0.1 \%(\mathrm{w} / \mathrm{v})$ sucrose or glucose. Plates were incubated in an atmosphere not supplemented with $\mathrm{CH}_{4}$. To ensure detection of slowly growing heterotrophic satellites, growth was assessed after incubation for 4 weeks at $25^{\circ} \mathrm{C}$.
Finally, DNA was extracted from two separate batches of strain $\mathrm{BL} 2^{\mathrm{T}}$ and PCR-amplified partial fragments of the $16 \mathrm{~S}$ rRNA gene were analysed by denaturing gradient gel electrophoresis to determine whether only a single gene product was detectable in the cultures. All steps were performed as described previously (Henckel et al., 1999) except that the PCR mixtures all contained premix F (Epicenter Technologies) instead of $1.5 \mathrm{mM} \mathrm{MgCl}_{2}$, and the denaturing gradient gel electrophoresis gel was run at $150 \mathrm{~V}$ for $6 \mathrm{~h}$.

Morphological observations. Cell morphology was examined in batch cultures grown in liquid DNMS for 2 weeks (in vials sealed with butyl-rubber stoppers and injected with $\mathrm{CH}_{4}$ at $10 \%, \mathrm{v} / \mathrm{v}$ ). The presence of cysts or exospores was examined using stationary-phase liquid and plate cultures (up to 4-5 months old) (Dedysh et al., 2000).

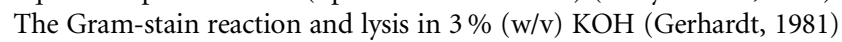
were performed on both 1 - and 3 -week-old cultures. Lysis by $0 \cdot 2$ and $2 \%(\mathrm{w} / \mathrm{v})$ SDS was determined by direct microscopic observation.

Electron microscopy. Cells were collected by centrifugation and fixed for $1 \mathrm{~h}$ at $4{ }^{\circ} \mathrm{C}$ in $0.15 \mathrm{M}$ cacodylate buffer ( $\mathrm{pH} 7 \cdot 3$ ) containing $0 \cdot 1 \%(\mathrm{w} / \mathrm{v})$ ruthenium red and $1 \cdot 2 \%(\mathrm{w} / \mathrm{v})$ glutaraldehyde. Cells were then washed three times with $0 \cdot 15 \mathrm{M}$ cacodylate buffer $(\mathrm{pH} 7 \cdot 3$ ) by centrifugation ( $3 \mathrm{~min}$ at $3000 \mathrm{~g}$ ). Cells were additionally fixed for $3 \mathrm{~h}$ at $20^{\circ} \mathrm{C}$ in a solution containing $1.5 \%(\mathrm{w} / \mathrm{v}) \mathrm{OsO}_{4}$ and $0.1 \%(\mathrm{w} / \mathrm{v})$ ruthenium red in $0.05 \mathrm{M}$ cacodylate buffer $(\mathrm{pH} 7 \cdot 3$ ) and then washed with $0 \cdot 15 \mathrm{M}$ cacodylate buffer $(\mathrm{pH} 7 \cdot 3$ ). Thin-sectioning, staining and transmission electron microscopy were performed as described previously (Dedysh et al., 2000).

Physiological tests. To test the $\mathrm{pH}$ range, DNMS containing $1.25 \mathrm{mM}$ phosphate buffer was adjusted to $\mathrm{pH} 4-7 \cdot 5$ (in steps of $0.5 \mathrm{pH}$ units) with $\mathrm{H}_{3} \mathrm{PO}_{4}$. Duplicate $120 \mathrm{ml}$ serum vials $(40 \mathrm{ml}$ medium) at each $\mathrm{pH}$ were capped with butyl-rubber stoppers and injected with $10 \%(\mathrm{v} / \mathrm{v}) \mathrm{CH}_{4}$. The $\mathrm{OD}_{600}$ was measured in an Eppendorf BioPhotometer at 2-day intervals for 2 weeks. Growth at temperatures from 4 to $45^{\circ} \mathrm{C}$ and tolerance of $\mathrm{NaCl}$ concentrations from 0.01 to $1 \%(\mathrm{w} / \mathrm{v})$ were also determined in liquid DNMS cultures monitored for 2 weeks (Dedysh et al., 2000).

Nitrogen fixation was assayed using the acetylene-reduction procedure of Takeda (1988). Batch cultures in nitrogen-free DNMS medium containing $0.5 \%(\mathrm{v} / \mathrm{v})$ methanol were assayed in the mid-exponential growth phase. Incubations with acetylene were performed under both aerobic and microaerobic conditions, using the protocol described for Methylocella palustris (Dedysh et al., 2000).

Range of utilizable carbon and nitrogen sources. The range of potential growth substrates was examined using $0.05 \%(\mathrm{w} / \mathrm{v})$ concentrations of the following carbon sources: formate, formamide, methylamine, dimethylamine, trimethylamine, glucose, fructose, sucrose, lactose, galactose, xylose, sorbose, maltose, raffinose, arabinose, ribose, lactate, oxalate, citrate, mannitol and sorbitol. The capacity to utilize methanol at concentrations from 0.01 to $6 \%(\mathrm{v} / \mathrm{v})$ was determined in DNMS liquid medium supplemented with methanol (vials were capped with butyl-rubber stoppers to prevent loss of methanol by vaporization). Nitrogen sources were tested by replacing $\mathrm{KNO}_{3}$ in DNMS with $0.05 \%$ (w/v) $\mathrm{NaNO}_{2}, \mathrm{NH}_{2} \mathrm{OH},\left(\mathrm{NH}_{4}\right)_{2} \mathrm{SO}_{4}, \mathrm{NH}_{4} \mathrm{Cl}$, glycine, L-alanine, L-serine, L-isoleucine, L-proline, L-cystine, Lmethionine, L-glutamine, L-histidine, L-arginine, L-lysine or yeast extract. Growth was examined, after incubation for 30 days, in comparison with a negative control (i.e. growth on nitrogen-free DNMS medium).

Preparation of cell-free extract. Cells grown under $\mathrm{CH}_{4}$ (1-2 weeks) were harvested by centrifugation $(15000 \mathrm{~g}, 20 \mathrm{~min})$ and washed in $0.05 \mathrm{M}$ Tris/ $\mathrm{HCl}$ buffer $(\mathrm{pH} \mathrm{7.2)}$ containing $5 \mathrm{mM}$ $\mathrm{MgCl}_{2}$. Cells ( $1 \mathrm{~g}$ fresh weight) were resuspended in $5 \mathrm{ml}$ of the same buffer; $1 \mathrm{ml}$ of a solution containing $1 \mathrm{mg}$ lysozyme (Sigma) was added and the resulting mixture was incubated for $3 \mathrm{~h}$ at $20^{\circ} \mathrm{C}$. The suspension was centrifuged $(15000 \mathrm{~g}, 20 \mathrm{~min})$, washed in $0.05 \mathrm{M}$ 
Tris/HCl buffer ( $\mathrm{pH} \mathrm{7 \cdot 2)}$ containing $5 \mathrm{mM} \mathrm{MgCl}_{2}$ and $0 \cdot 1 \mathrm{mM}$ PMSF, resuspended in the same buffer, sonicated $(3 \times 30 \mathrm{~s})$ and centrifuged $(15000 \mathrm{~g}, 40 \mathrm{~min})$. The soluble fraction was used to measure enzyme activities.

Enzyme assays. Enzymic studies were performed as described for Methylocella palustris $\mathrm{K}^{\mathrm{T}}$ (Dedysh et al., 2000). To test for sMMO activity, naphthol formation from naphthalene was monitored with tetrazotized $o$-dianisidine according to the procedure of Phelps et al. (1992). sMMO activity was measured in whole cells grown in either copper-deficient medium (with no added copper) or at copper excess $\left(2 \cdot 5 \mu \mathrm{M} \mathrm{Cu}^{2+}\right)$. MMO activity was also estimated as the velocity of radioactivity incorporation from ${ }^{14} \mathrm{CH}_{4}$ into both cells and $\mathrm{CO}_{2}$. Cells were grown to an $\mathrm{OD}_{600}$ of $0 \cdot 3-0 \cdot 5$, harvested by centrifugation $(10000 \mathrm{~g}, 20 \mathrm{~min})$, washed in $10 \mathrm{mM}$ potassium phosphate buffer ( $\mathrm{pH} \mathrm{6.5)}$ and then resuspended in the same buffer containing $10 \mathrm{mM}$ sodium formate. Aliquots $(1 \mathrm{ml})$ of the cell suspension were placed into $15 \mathrm{ml}$ vials, which were capped and sealed; $100 \mu \mathrm{l}^{14} \mathrm{CH}_{4}$ $\left(2 \mu \mathrm{Ci} \mu \mathrm{mol}^{-1}\right)$ was injected into the gas phase and the vials were incubated at $20^{\circ} \mathrm{C}$. After 10,20 or $30 \mathrm{~min}, 1 \mathrm{ml} 2 \mathrm{M} \mathrm{NaOH}$ was added with a syringe to stop all metabolic processes and to absorb all ${ }^{14} \mathrm{CO}_{2}$ evolved. After 1 day, $0 \cdot 2 \mathrm{ml}$ culture samples were taken, placed onto Whatman GF/F glass-fibre papers $(1.5 \times 1.5 \mathrm{~cm})$ and air-dried. Papers were rinsed with $0.2 \mathrm{ml}$ distilled water and dried again. Radioactivity was measured on an Intertechnique SL-30 liquid scintillation spectrometer.

Comparative sequence analysis. DNA to be used in PCRs was extracted from strains $B L 2^{\mathrm{T}}$ and $\mathrm{A} 1$ using a mechanical disruption procedure (Henckel et al., 1999). PCR-mediated amplification of the 16S rRNA gene from position 28 to 1491 (numbering according to the International Union of Biochemistry nomenclature for Escherichia coli 16S rRNA), as well as of a partial fragment of the $m \times a F$ gene, was carried out as described previously (Dedysh et al., 2000). Partial fragments of the $m m o X$ gene (encoding a subunit of sMMO) and of the nifH gene (encoding dinitrogenase reductase $\mathrm{H}$ ) were amplified using primers and PCR programs described, respectively, by Auman et al. (2000) and Auman et al. (2001). In each case, PCR mixtures contained $0.5 \mu \mathrm{M}$ each primer, $1 \times$ Premix F (Epicenter Technologies) and $1 \mathrm{U}$ Taq polymerase (QBioGene). Sequencing was performed as described previously (Dedysh et al., 2000) and comparative phylogenetic analysis was carried out using the ARB program package (Strunk \& Ludwig, 1996).

DNA base composition and DNA-DNA hybridization. Cultures of strain $\mathrm{BL} 2^{\mathrm{T}}$ and Methylocella palustris $\mathrm{K}^{\mathrm{T}}$ were grown on DNMS plates for 8 weeks. Cells were separated from their capsular matrix by a combination of heating to $50^{\circ} \mathrm{C}$ and vigorous shaking. DNA extraction and DNA-DNA hybridization of the two strains were performed as described by Martin et al. (1997). The G+C content of the DNA was analysed as described by Groth et al. (1996).

Analysis of fatty acid methyl esters. Fatty acid methyl esters were extracted from cells and analysed by GC as described by Kämpfer \& Kroppenstedt (1996).

\section{RESULTS}

\section{Colony morphology of strains $\mathrm{BL2}^{\mathrm{T}}$ and $\mathrm{A} 1$ and growth in liquid medium}

Raised, white, circular colonies with an entire edge and a smooth surface developed on DNMS agar after incubation for 1-2 weeks. Six-week-old colonies were $2-4 \mathrm{~mm}$ in diameter. With continued growth, the colonies developed a semi-transparent layer over the original white colony form and eventually merged together to form an amorphous slimy cover on the agar surface. Liquid cultures displayed white turbidity; a surface pellicle was not formed. In high concentrations of methanol $(0 \cdot 5-5 \%, v / v)$, liquid cultures first developed white turbidity and later became semitransparent and highly viscous.

\section{Cell morphology and ultrastructure}

Cells of strains $\mathrm{BL}^{\mathrm{T}}$ and $\mathrm{A} 1$ were Gram-negative, nonmotile, short, slightly curved rods, $0 \cdot 6-0 \cdot 8 \mu \mathrm{m}$ in width and $1 \cdot 2-1 \cdot 5 \mu \mathrm{m}$ in length. They reproduced by normal cell division. Similarly to Methylocella palustris, the cells had a distinctive bipolar appearance which was more or less pronounced depending on the culture conditions. Cells occurred singly or as aggregates in which each cell was separated from the others by the capsular material. This material stained with ruthenium red (Luft, 1964) and was therefore polysaccharidic in nature (Fig. 1a-c). The formation of rosettes was not observed. Although both plate and liquid cultures up to 5 months old were thoroughly examined, no spores or other resting stages were observed.

Thin sections were prepared from both methane- and methanol-grown cells. Methane-grown cells had an ICM composed of flattened, ovoid or tube-shaped vesicles oriented irregularly on the periphery of the cytoplasm (Fig. 1d, e). Ovoid vesicles were occasionally combined into chains (Fig. 1e). It is possible that these ovoid vesicles originated through division of the long tube-shaped vesicles. All three types of vesicle (flattened, tube-shaped and ovoid) were bounded by three-layered membranes, and each contained a homogeneous matrix of lower electron density with respect to the cytoplasm. In methanol-grown cells, small ovoid vesicles combined into chains on the cell periphery were predominant (Fig. 1a, b). These ICM structures were similar to those of Methylocella palustris (Dedysh et al., 2000), except that the vesicles in Methylocella palustris were smaller and more spherical. Methanol-grown cells contained one large inclusion of poly- $\beta$-hydroxybutyrate per cell (Fig. 1f).

\section{Culture purity}

Both isolates displayed a uniform cell morphology in cultures of different age. No growth was observed either on any of the complex organic plating media tested or on various multicarbon substrates in liquid culture. Finally, only a single $16 \mathrm{~S}$ rRNA gene product (as determined by denaturing gradient gel electrophoresis analysis) could be amplified by PCR from DNA of cultures of strain BL2 ${ }^{\mathrm{T}}$.

\section{Physiological characteristics}

Strains $\mathrm{BL} 2^{\mathrm{T}}$ and $\mathrm{A} 1$ grew on methane or methanol as the sole carbon and energy source. Slow growth was also observed on ammonium formate and on methylamine. In contrast to Methylocella palustris, which did not grow at methanol concentrations above $0 \cdot 3 \%$, the isolates from forest soil utilized methanol at a wide range of concentrations $(0 \cdot 01-5 \%)$. The optimum was between $0 \cdot 5$ and $2 \%$. Cells 

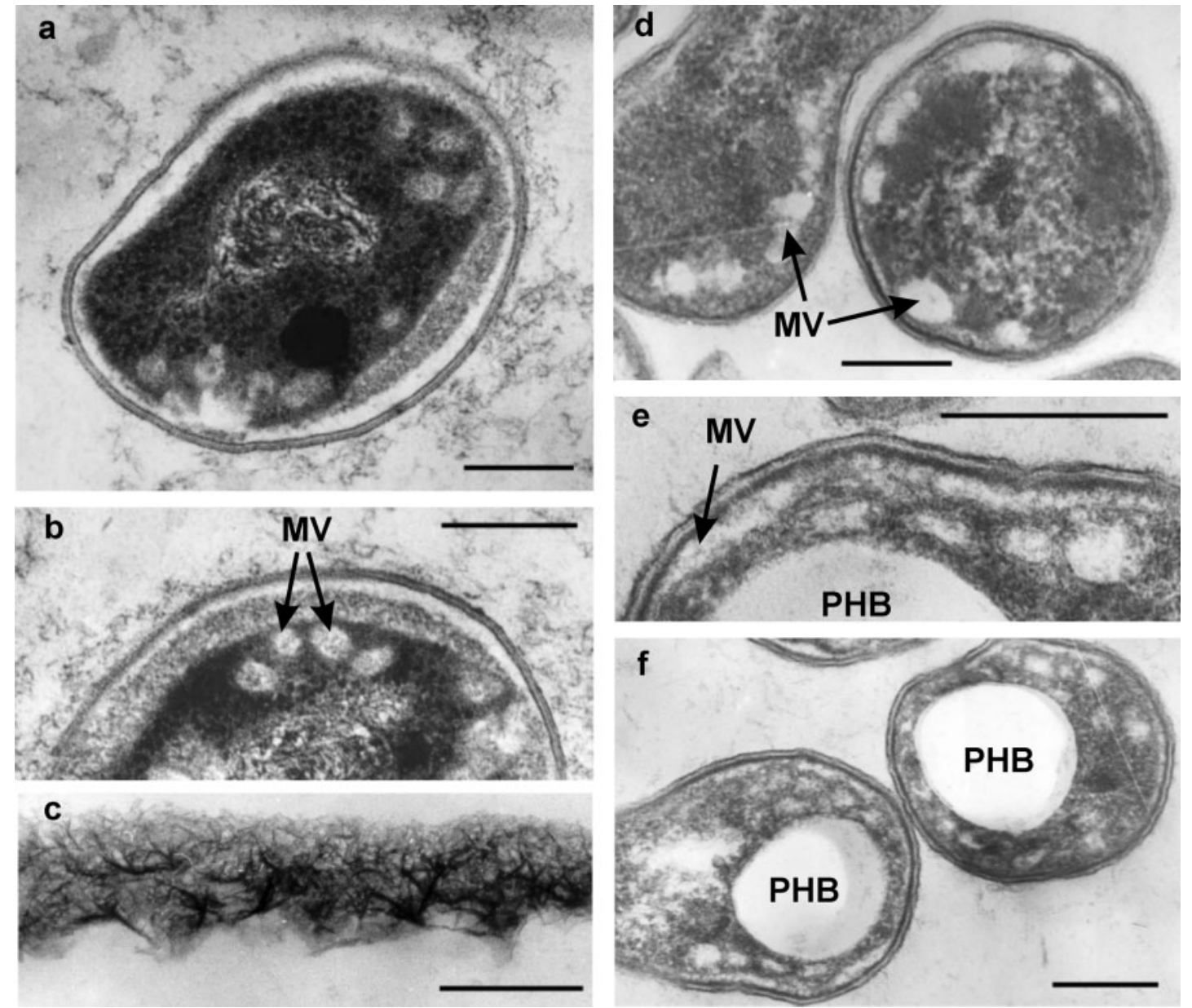

Fig. 1. Electron micrographs of ultrathin sections of cells of strain $B L 2^{\top}$ grown on methanol $(a, b, f)$ and on methane (c-e). Chains of flattened and ovoid membrane vesicles located on the cell periphery are shown $(a, b, d-f)$ (MV, membrane vesicles). Large granules of poly- $\beta$-hydroxybutyrate (PHB) are visible in methanol-grown cells (f). The fibrous structure of the polysaccharide capsule of strain $B L 2^{\top}$ can be seen (c). The polysaccharide capsule is not visible around all cells $(a, b, d-f)$, as it became detached during cell preparation. Bars, $0 \cdot 2 \mu \mathrm{m}$.

grown at higher methanol concentrations (3-5\%) had large capsules up to 5-8 $\mu \mathrm{m}$ in diameter. Growth did not occur on the other $\mathrm{C}_{1}$ or multicarbon compounds tested. Growth factors were not required. Both strains utilized ammonium salts, nitrates and yeast extract as nitrogen sources. Weak growth also occurred when L-alanine, L-serine, L-cystine, Lglutamine and L-proline were provided as nitrogen sources. Although the isolates were also capable of growth on nitrogen-free agar medium, they grew poorly under aerobic conditions in liquid nitrogen-free medium. Acetylenereduction activity by strains $\mathrm{BL} 2^{\mathrm{T}}$ and $\mathrm{A} 1$ was detectable only in microaerobic conditions and ranged from $4 \cdot 0$ to $5 \cdot 5 \mathrm{nmol} \mathrm{C}_{2} \mathrm{H}_{4}$ (mg dry biomass) ${ }^{-1} \mathrm{~h}^{-1}$. The amplification of a nifH gene from strain $\mathrm{BL}^{\mathrm{T}}$ provides additional evidence that the genetic potential for nitrogen fixation is present.

The $\mathrm{pH}$ of the medium was altered by the growth of the culture, so the strict $\mathrm{pH}$ dependence was difficult to determine. However, no growth occurred at $\mathrm{pH} 4$ or $7 \cdot 5$.
The fastest growth occurred at $\mathrm{pH} 5 \cdot 5$ and, after growth for 2 weeks in media with initial $\mathrm{pH}$ values between 5 and $6 \cdot 5$, the final $\mathrm{pH}$ tended to be about $5 \cdot 8$. The temperature range for growth was $4-30{ }^{\circ} \mathrm{C}$, with the optimum at $15-25^{\circ} \mathrm{C}$. No growth occurred at $37^{\circ} \mathrm{C}$. The specific growth rate of culture under $\mathrm{CH}_{4}\left(10 \%\right.$, v/v), calculated from increases in $\mathrm{OD}_{600}$ in the exponential phase (10 days) of growth (a mean of 10 vials), was 0.33 day $^{-1}$ (equal to a doubling time of $2 \cdot 1$ days). Like Methylocella palustris, the forest isolates grew better on diluted media, but the optimum salt concentration was about twice as high $\left(0 \cdot 4-1 \cdot 0 \mathrm{~g}\right.$ salts $\left.1^{-1}\right)$ (Dedysh et al., 2000). Growth was inhibited completely by $\mathrm{NaCl}$ concentrations above $0 \cdot 8 \%$.

\section{Cellular fatty acid profiles}

Overall, the cellular fatty acid composition of strain $B L 2^{\mathrm{T}}$ was quite similar to those of Methylocella palustris $\mathrm{K}^{\mathrm{T}}$ and Methylocapsa acidiphila $\mathrm{B}^{\mathrm{T}}$ (Table 1). The distinguishing 
features of the phospholipid fatty acid profile of strain BL2 ${ }^{\mathrm{T}}$ compared with Methylocella palustris $\mathrm{K}^{\mathrm{T}}$ were the presence of the i17:0, i18:0 and 19:0 fatty acids and a lower total content of $\mathrm{C}_{16}$ fatty acids.

\section{Metabolic pattern}

Cell suspensions of strain $\mathrm{BL} 2^{\mathrm{T}}$ grown under $\mathrm{CH}_{4}$ oxidized ${ }^{14} \mathrm{C}$-methane at $20 \mathrm{nmol} \mathrm{min}{ }^{-1}(\mathrm{mg} \text { protein })^{-1}$, regardless of the copper content of the medium. Cells grown in medium without added copper or with a low $\mathrm{Cu}^{2+}$ concentration $(0.3 \mu \mathrm{M})$ oxidized naphthalene at the same rate, implying that sMMO was responsible for methane oxidation. A twofold lower naphthalene-oxidation rate $\left[10 \mathrm{nmol} \mathrm{min}{ }^{-1}(\mathrm{mg} \text { protein })^{-1}\right]$ was observed in cells grown in copper excess $(2 \cdot 5 \mu \mathrm{M})$. However, this occurred without a decrease in total MMO activity (measured with ${ }^{14} \mathrm{CH}_{4}$ ). These data may imply the presence of pMMO in this organism.

Cell-free extracts of strain $\mathrm{BL} 2^{\mathrm{T}}$ displayed activities of

Table 1. Cellular fatty acid compositions of isolate $B L 2^{\top}$ and other type II methanotrophs

Taxa/strains: 1, Methylocella silvestris sp. nov. $\mathrm{BL}_{2}^{\mathrm{T}} ; 2$, Methylocella palustris $\mathrm{K}^{\mathrm{T}}$ (data from Dedysh et al., 2002); 3, Methylocapsa acidiphila $\mathrm{B}^{\mathrm{T}}$ (Dedysh et al., 2002); 4, Methylosinus and Methylocystis spp. (Bowman et al., 1993). a, Anteiso; br, branched; cy, cyclo; i, iso.

\begin{tabular}{|c|c|c|c|c|}
\hline Fatty acid & 1 & 2 & 3 & 4 \\
\hline i15: 0 & $1 \cdot 2$ & $0 \cdot 2$ & $0 \cdot 1$ & $0-0 \cdot 9$ \\
\hline a $15: 0$ & 0 & 0 & 0 & $0-3 \cdot 5$ \\
\hline $15: 0$ & 0 & $0 \cdot 1$ & 0 & $0-0 \cdot 7$ \\
\hline i16:0 & 0 & 0 & 0 & $0-1 \cdot 4$ \\
\hline $16: 1 \omega 7 c$ & $8 \cdot 8$ & $6 \cdot 8$ & $4 \cdot 7$ & $0 \cdot 3-14 \cdot 2$ \\
\hline $16: 1 \omega 7 t$ & 0 & $5 \cdot 8$ & 0 & 0 \\
\hline $16: 1 \omega 6 c$ & 0 & 0 & 0 & $0-0 \cdot 3$ \\
\hline $16: 1 \omega 5 c$ & 0 & $0 \cdot 1$ & $0 \cdot 1$ & $0-0 \cdot 2$ \\
\hline $16: 0$ & $3 \cdot 0$ & $5 \cdot 9$ & $7 \cdot 3$ & $0 \cdot 7-5 \cdot 1$ \\
\hline $\mathrm{i} 17: 1 \omega 7 c$ & 0 & $0 \cdot 1$ & 0 & 0 \\
\hline i17 : 0 & $2 \cdot 5$ & 0 & 0.6 & $0-0 \cdot 3$ \\
\hline a17:0 & 0 & $0 \cdot 3$ & 0 & $0-0 \cdot 6$ \\
\hline $17: 1 \omega 8 c$ & 0 & $0 \cdot 3$ & 0 & $0-0 \cdot 2$ \\
\hline $17: 1 \omega 7 c$ & 0 & 0 & $1 \cdot 0$ & $0-0 \cdot 7$ \\
\hline $17: 1 \omega 6 c$ & 0 & $0 \cdot 1$ & 0 & $0-0 \cdot 1$ \\
\hline $17: 0$ & 0 & $0 \cdot 1$ & $0 \cdot 1$ & $0-0 \cdot 4$ \\
\hline i18:0 & $0 \cdot 5$ & 0 & 0 & 0 \\
\hline cy18:0 & 0 & 0 & 0 & $0-6 \cdot 5$ \\
\hline $18: 1 \omega 8 c$ & 0 & 0 & 0 & $52 \cdot 9-73 \cdot 6$ \\
\hline $18: 1 \omega 7 c$ & $82 \cdot 2$ & $78 \cdot 6$ & $78 \cdot 3$ & $14 \cdot 8-37 \cdot 7$ \\
\hline $18: 1 \omega 7 t$ & 0 & 0 & 0 & $0-4 \cdot 6$ \\
\hline $18: 1 \omega 5 c$ & 0 & $0 \cdot 1$ & 0 & $0-0 \cdot 2$ \\
\hline $18: 0$ & $1 \cdot 2$ & 0.9 & $7 \cdot 6$ & $0-5 \cdot 0$ \\
\hline br19: 1 & 0 & 0 & 0 & $0-0 \cdot 2$ \\
\hline cy19:0 & 0 & 0 & 0 & $0-0 \cdot 4$ \\
\hline $19: 0$ & $0 \cdot 6$ & 0 & 0 & 0 \\
\hline
\end{tabular}

serine-pathway-specific enzymes (hydroxypyruvate reductase and serine-glyoxylate aminotransferase) but not of the key RuMP-cycle enzyme hexulosephosphate synthase or of key enzymes of the ribulose 1,5-bisphosphate cycle (ribulose bisphosphate carboxylase/oxygenase and phosphoribulokinase) (Table 2). Activity of 2-oxoglutarate dehydrogenase was also detected, indicating that the complete tricarboxylic acid cycle operates in this methanotroph. However, glyoxylatecycle enzymes were absent. Pyrophosphate-dependent 6phosphofructokinase and fructose-1,6-bisphosphate aldolase were present. Also, high activities of the pentose-phosphatecycle enzymes (glucose-6-phosphate and 6-phosphogluconate dehydrogenases) were measured in cell extracts. In general, the metabolic pattern of $\mathrm{BL}_{2}{ }^{\mathrm{T}}$ is similar to those of Methylocella palustris and Methylocapsa acidiphila (Dedysh et al., 2000, 2002).

\section{Phylogenetic analysis and DNA-DNA hybridization}

A phylogenetic tree constructed on the basis of nearly complete (at least 1350 bases) 16S rRNA gene sequences (Fig. 2) indicated that strains BL2 ${ }^{\mathrm{T}}$ and A1 belong to the $\alpha$ subclass of the Proteobacteria. The closest neighbours are Methylocella palustris $\mathrm{K}^{\mathrm{T}}$ ( $2 \cdot 7 \%$ sequence difference), B. indica subsp. indica ATCC $9039^{\mathrm{T}}(2 \cdot 9 \%)$ and Methylocapsa acidiphila $\mathrm{B}^{\mathrm{T}}(3 \cdot 8 \%)$. The DNA-DNA hybridization value of strain $\mathrm{BL2}^{\mathrm{T}}$ with its closest phylogenetic neighbour (Methylocella palustris $\mathrm{K}^{\mathrm{T}}$ ) was therefore determined and was found to be only 21-22\%. DNA-DNA hybridization was not carried out with $B$. indica because this bacterium is a non-methanotrophic heterotroph. This critical phenotypic difference alone is sufficient to rule out the inclusion of the isolates in the genus Beijerinckia.

A phylogenetic analysis based on partial $m m o X$ sequences also indicated that, among sMMO-containing methanotrophs, the closest neighbour of strains $\mathrm{BL}_{2}{ }^{\mathrm{T}}$ and $\mathrm{A} 1$ was Methylocella palustris $\mathrm{K}^{\mathrm{T}}(10 \cdot 3-10 \cdot 5 \%$ nucleotide sequence difference, $3 \cdot 3-3 \cdot 4 \%$ derived amino acid sequence difference), followed by other type II methanotrophs of the genera Methylosinus and Methylocystis (Fig. 3). The partial mxaF nucleotide sequences of strains BL2 ${ }^{\mathrm{T}}$ and $\mathrm{A} 1$ differed from that of Methylocella palustris $\mathrm{K}^{\mathrm{T}}$ by $18 \cdot 8-20 \cdot 5 \%(14 \cdot 9$ $15.9 \%$ derived amino acid sequence difference) and it was not evident from $m x a F$ sequence-based phylogeny that they were closer phylogenetically to Methylocella palustris than to other methylotrophic bacteria (data not shown).

A pmoA product (the active-site polypeptide of pMMO) could not be amplified by PCR with any of the following three primer sets for this gene: A189/A682 (Holmes et al., 1995), A189/mb661r (Costello \& Lidstrom, 1999) and A189/ A648b (Dunfield et al., 2002).

\section{DISCUSSION}

Until now, the methanotrophic genus Methylocella has been represented by a single species isolated from peat bogs in 
Table 2. Activities of enzymes of primary and intermediate metabolism in cell extracts of isolate $B L 2^{\top}$

PMS, Phenazine methosulfate; PPi, pyrophosphate.

\begin{tabular}{|c|c|c|}
\hline Enzyme & Co-factor & Activity $\left[\mathrm{nmol} \min ^{-1}(\mathrm{mg} \text { protein })^{-1}\right]$ \\
\hline Methane monooxygenase (soluble) & - & 20 \\
\hline Methanol dehydrogenase & PMS & 137 \\
\hline Formaldehyde dehydrogenase & PMS & 4 \\
\hline \multirow[t]{2}{*}{ Formate dehydrogenase } & NAD & 10 \\
\hline & PMS & 22 \\
\hline Ribulose-1,5-bisphosphate carboxylase & - & 0 \\
\hline Hexulosephosphate synthase & - & 0 \\
\hline Phosphoribulokinase & ATP & 0 \\
\hline \multirow{2}{*}{ Hydroxypyruvate reductase } & NADH & 64 \\
\hline & NADPH & 0 \\
\hline Serine-glyoxylate aminotransferase & - & 28 \\
\hline \multirow[t]{2}{*}{ 6-Phosphofructokinase } & PPi & 27 \\
\hline & ATP & 0 \\
\hline Fructose-1,6-bisphosphate aldolase & - & 22 \\
\hline \multirow[t]{2}{*}{ Glucose-6-phosphate dehydrogenase } & NAD & 133 \\
\hline & NADP & 16 \\
\hline \multirow[t]{2}{*}{ 6-Phosphogluconate dehydrogenase } & NAD & 113 \\
\hline & NADP & 15 \\
\hline 2-Keto-3-deoxy-6-phosphogluconate aldolase & - & 0 \\
\hline \multirow[t]{2}{*}{ Isocitrate dehydrogenase } & NAD & 0 \\
\hline & NADP & 8 \\
\hline 2-Oxoglutarate dehydrogenase & NAD & 12 \\
\hline Glutamate dehydrogenase & $\mathrm{NADH}$ & 8 \\
\hline Malate synthase & - & 0 \\
\hline Isocitrate lyase & - & 0 \\
\hline
\end{tabular}

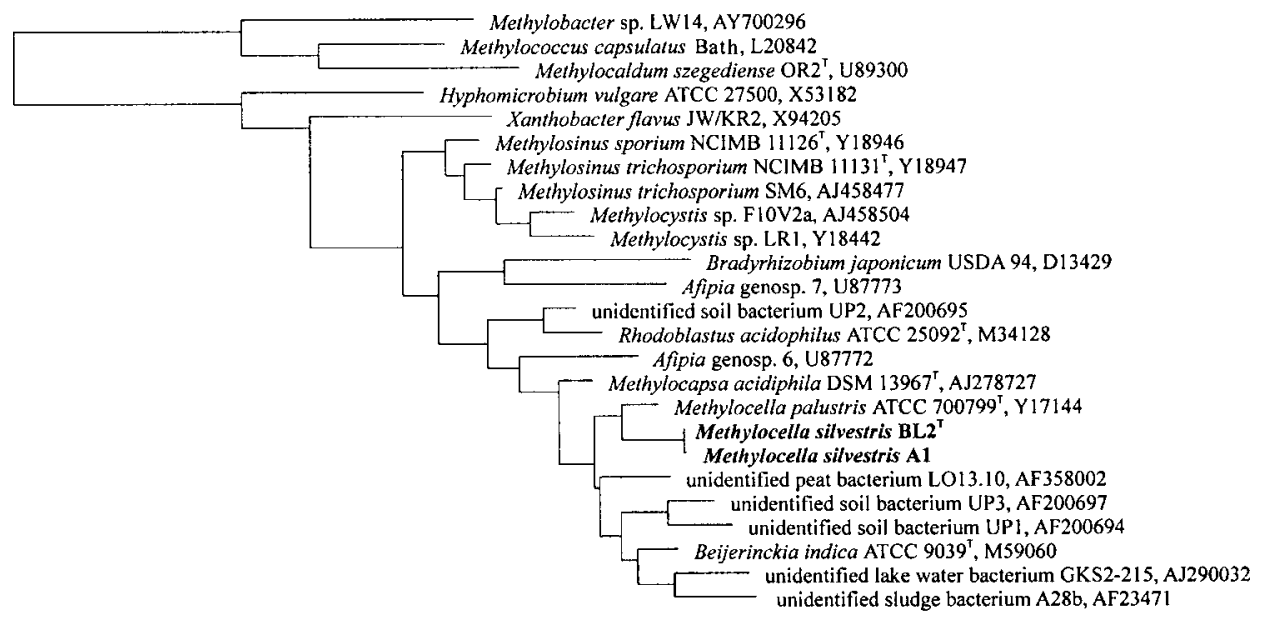

Fig. 2. Maximum-likelihood phylogenetic tree based on nearly complete $16 \mathrm{~S}$ rRNA gene sequences, showing the positions of strains $B 2^{\top}$ and $A 1$ relative to selected $\alpha$-Proteobacteria and relative to gene sequences retrieved in cultivation-independent studies. The type I methanotrophs Methylococcus capsulatus Bath, Methylobacter sp. LW14 and Methylocaldum szegediense OR $2^{\top}$ were used as an outgroup. Bar, $0 \cdot 1$ changes per nucleotide position. 


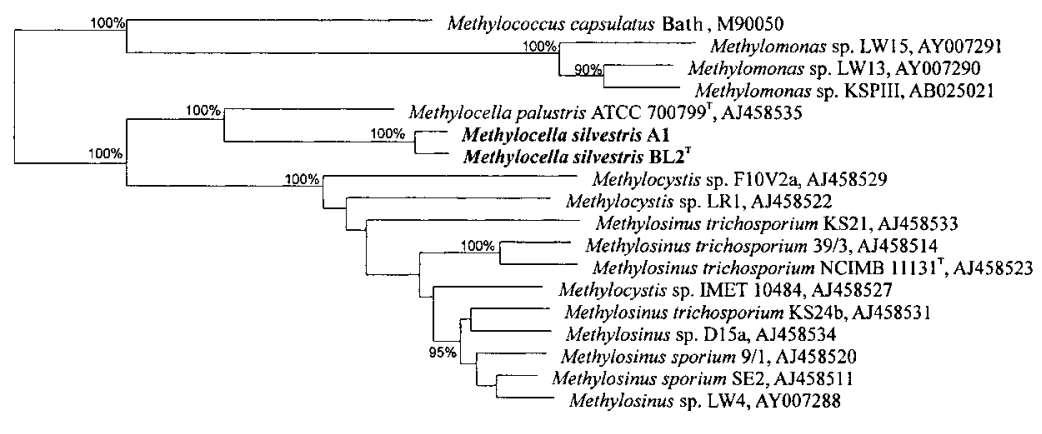

0.10
Fig. 3. Neighbour-joining tree (Jukes-Cantor correction) constructed using partial $\mathrm{mmoX}$ nucleotide sequences, showing the positions of strains $A 1$ and $B L 2^{\top}$ relative to other type I and II methanotrophs. Bootstrap values (100 data resamplings) $>90 \%$ are shown. Bar, $0 \cdot 1$ changes per nucleotide position. western Siberia and northern Russia (Dedysh et al., 1998, 2000). The isolation of Methylocella strains $B L 2^{\mathrm{T}}$ and $\mathrm{A} 1$ from a forest soil extends the known phylogenetic and ecological diversity of this genus. The forest strains were phenotypically and phylogenetically most similar to Methylocella palustris among known bacteria. However, minor phenotypic differences were evident between Methylocella palustris $\mathrm{K}^{\mathrm{T}}$ and strain $\mathrm{BL} 2^{\mathrm{T}}$, sequence-based phylogenetic identities were low compared with identities among other closely related methanotrophic genera and the DNA-DNA hybridization was only $21-22 \%$, indicating that the forest strains should be considered as representing a novel species (Wayne et al., 1987; Stackebrandt \& Goebel, 1994).

Bacteria of the genus Methylocella lack an extensive ICM system and appear to consume methane primarily via sMMO instead of the pMMO that is associated with the ICM systems of other methanotrophs. The sMMO activity in strain $\mathrm{BL} 2^{\mathrm{T}}$ was only partially decreased by a level of copper $(2 \cdot 5 \mu \mathrm{M})$ that completely inhibited sMMO activity in Methylosinus trichosporium $\mathrm{OB}^{\mathrm{T}} \mathrm{b}^{\mathrm{T}}$ (Morton et al., 2000). It is reasonable that inhibition or repression of sMMO should not occur in Methylocella strains if they do not contain pMMO as an alternative to sMMO. However, we cannot rule out the presence of pMMO in strain $\mathrm{BL} 2^{\mathrm{T}}$. In ${ }^{14} \mathrm{CH}_{4}$ experiments, MMO activity remained constant under conditions that lowered sMMO activity by $50 \%$.

In contrast to alkaliphilic species, which are represented mostly by type I methanotrophs and grow well at high external salinities (Trotsenko \& Khmelenina, 2002), acidophilic methanotrophs grow only in media with a low dissolved salt content. This interesting feature deserves further study, which may lead to a better understanding of the main principles of adaptation and survival of acidophilic and alkaliphilic methanotrophs.

The cambisol from which strains $\mathrm{BL} 2^{\mathrm{T}}$ and $\mathrm{A} 1$ were obtained has a $\mathrm{pH}$ of $3 \cdot 8-4 \cdot 3$. This is typical of most forested soils of the temperate zone, so it is possible that members of the genus Methylocella are widespread geographically, in terrestrial soil as well as in wetlands. The methanotroph community of this cambisol has been characterized using cultivation-independent molecular methods (Henckel et al., 2000). This study failed to detect methanotrophs related to Methylocella species. However, the primer systems used targeted only (i) the pmoA gene, which is not detectable in strain $\mathrm{BL} 2^{\mathrm{T}}$, and (ii) the $16 \mathrm{~S}$ rRNA gene, from which only the most abundant members of the entire bacterial community are expected to be retrieved. Cultivation of Methylocella strains adds to the known diversity of the methanotroph community in this forest soil; it also demonstrates the method-inherent limitations of cultivation-independent techniques in the exhaustive characterization of a microbial community. Cultivation-independent analysis did identify a pmoA sequence cluster somewhat related to the $p m o A$ of

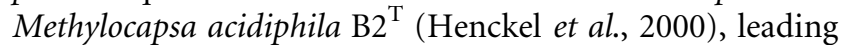
to the hypothesis that more, as yet uncultivated, acidophilic methanotrophs exist.

Forest soils periodically produce methane in anaerobic microsites, especially when water-saturated (e.g. Yavitt et al., 1990; Wang \& Bettany, 1997; Andersen et al., 1998), and are therefore a potential habitat for methanotrophic bacteria. These soils also consume methane from the atmosphere, but it is unlikely that methanotrophs possessing only sMMO are responsible for this activity. The pMMO form of the enzyme has a higher affinity for methane than does sMMO (Hanson \& Hanson, 1996) and is a more probable candidate for the consumption of the trace (1.7 p.p.m.v.) level of $\mathrm{CH}_{4}$ in the atmosphere. When batch cultures of strain $\mathrm{BL} 2^{\mathrm{T}}$ were cultivated in closed flasks, the threshold $\mathrm{CH}_{4}$ concentration below which no more consumption occurred was always $>100$ p.p.m.v. (data not shown). On the basis of the growth conditions used, it is therefore unlikely that strains $\mathrm{BL} 2^{\mathrm{T}}$ and A1 are capable of surviving on, or even of transiently consuming, atmospheric methane. We propose that these strains live on methanol or on methane produced in anaerobic soil microsites.

\section{Emended description of Methylocella Dedysh et al. 2000}

Methylocella (Me.thy.lo.cel'la. N.L. n. methylum the methyl group; L. n. cella a chamber, a cell; N.L. n. Methylocella methyl-using cell).

Cells are Gram-negative, polymorphic, straight or curved short rods, $0 \cdot 6-1 \cdot 0 \mu \mathrm{m}$ wide by $1 \cdot 0-2 \cdot 5 \mu \mathrm{m}$ long, with rounded ends. Produce large, highly refractile, intracellular poly- $\beta$-hydroxybutyrate granules, one at each pole. Reproduce by normal cell division. Cells occur singly or in 
irregularly shaped aggregates, but do not form rosettes. Non-motile. Encapsulated. Resting cells (if they occur) are exospores. Cells are not lysed by $2 \%$ SDS. The ICM system is different from those of both types I and II methanotrophic bacteria. Cells contain an extensive periplasmic space and a vesicular membrane system connected to the cytoplasmic membrane. Possess sMMO. The temperature range for growth is $4-30^{\circ} \mathrm{C}$ with an optimum at $15-25^{\circ} \mathrm{C}$; no growth occurs at $37^{\circ} \mathrm{C}$. Growth occurs at $\mathrm{pH} 4 \cdot 5-7 \cdot 0$. Highly sensitive to salt stress: prefer diluted media with a low salt content. Utilize $\mathrm{C}_{1}$ compounds via the serine pathway. Do not contain the enzymes of the RuMP and ribulose 1,5bisphosphate pathways. The tricarboxylic acid cycle is complete. Fix atmospheric nitrogen via an oxygen-sensitive nitrogenase. The major phospholipid fatty acids are $18: 1$ acids. The $\mathrm{G}+\mathrm{C}$ content of the DNA is $60-61 \mathrm{~mol} \%$. Phylogenetically related to, but clearly distinct from, the type II methanotroph genera Methylocystis and Methylosinus in the $\alpha$-subclass of the Proteobacteria; more closely affiliated with the acidophilic methanotrophic bacterium Methylocapsa acidiphila and the acidophilic heterotrophic bacterium $B$. indica. Distinguished from $B$. indica by the ability to consume methane. Habitats are acidic wetlands, particularly Sphagnum peat bogs, and acidic soils. The type species is Methylocella palustris.

\section{Description of Methylocella silvestris sp. nov.}

Methylocella silvestris (sil.ves'tris. L. adj. silvestris of the forest).

The description is as for the genus, with the following additional traits. Optimal growth occurs at $15-25^{\circ} \mathrm{C}$ and at $\mathrm{pH} 5 \cdot 5$. Capable of slow growth at $4{ }^{\circ} \mathrm{C}$. Carbon sources used include methane, methanol and methylamines. Utilizes methanol in a wide concentration range, from 0.01 to $5 \%$ $(\mathrm{v} / \mathrm{v}) . \mathrm{NaCl}$ inhibits growth at concentrations above $0 \cdot 8 \%$ $(\mathrm{w} / \mathrm{v})$. The type strain is strain BL2 ${ }^{\mathrm{T}}\left(=\mathrm{DSM} 15510^{\mathrm{T}}=\right.$ NCIMB $13906^{\mathrm{T}}$ ), which was isolated from an acidic cambisol under a beech-dominated forest near Marburg, Germany. The species also includes strain A1.

\section{ACKNOWLEDGEMENTS}

This research was supported, in part, by the Russian Fund for Basic Research (grants 02-04-04003 and 01-04-48511). We thank Nina Ringleff and Jürgen Heyer for technical assistance. Phospholipid fatty acid, $\mathrm{G}+\mathrm{C}$ content and DNA-DNA hybridization analyses were performed by the Deutsche Sammlung von Mikroorganismen und Zellkulturen (Braunschweig, Germany).

\section{REFERENCES}

Andersen, B. L., Bidoglio, G., Leip, A. \& Rembges, D. (1998). A new method to study simultaneous methane oxidation and methane production in soils. Global Biogeochem Cycles 12, 587-594.

Auman, A. J., Stolyar, S., Costello, A. M. \& Lidstrom, M. E. (2000). Molecular characterization of methanotrophic isolates from freshwater lake sediment. Appl Environ Microbiol 66, 5259-5266.
Auman, A. J., Speake, C. C. \& Lidstrom, M. E. (2001). nifH sequences and nitrogen fixation in type I and type II methanotrophs. Appl Environ Microbiol 67, 4009-4016.

Becking, J.-H. (1984). Genus Beijerinckia Derx 1950, $145^{\mathrm{AL}}$. In Bergey's Manual of Systematic Bacteriology, vol. 1, pp. 311-321. Edited by N. R. Krieg \& J. G. Holt. Baltimore: Williams \& Wilkins.

Bowman, J. P., Sly, L. I., Nichols, P. D. \& Hayward, A. C. (1993). Revised taxonomy of the methanotrophs: description of Methylobacter gen. nov., emendation of Methylococcus, validation of Methylosinus and Methylocystis species, and a proposal that the family Methylococcaceae includes only the group I methanotrophs. Int J Syst Bacteriol 43, 735-753.

Costello, A. M. \& Lidstrom, M. E. (1999). Molecular characterization of functional and phylogenetic genes from natural populations of methanotrophs in lake sediments. Appl Environ Microbiol 65, 5066-5074.

Dedysh, S. N., Panikov, N. S., Liesack, W., Großkopf, R., Zhou, J. \& Tiedje, J. M. (1998). Isolation of acidophilic methane-oxidizing bacteria from northern peat wetlands. Science 282, 281-284.

Dedysh, S. N., Liesack, W., Khmelenina, V. N., Suzina, N. E., Trotsenko, Y. A., Semrau, J. D., Bares, A. M., Panikov, N. S. \& Tiedje, J. M. (2000). Methylocella palustris gen. nov., sp. nov., a new methane-oxidizing acidophilic bacterium from peat bogs, representing a novel subtype of serine-pathway methanotrophs. Int J Syst Evol Microbiol 50, 955-969.

Dedysh, S. N., Khmelenina, V. N., Suzina, N. E., Trotsenko, Y. A., Semrau, J. D., Liesack, W. \& Tiedje, J. M. (2002). Methylocapsa acidiphila gen. nov., sp. nov., a novel methane-oxidizing and dinitrogen-fixing acidophilic bacterium from Sphagnum bog. Int J Syst Evol Microbiol 52, 251-261.

Dunfield, P. F., Tchawa Yimga, M., Dedysh, S. N., Berger, U., Liesack, W. \& Heyer, J. (2002). Isolation of a Methylocystis strain containing a novel pmoA-like gene. FEMS Microbiol Ecol 41, 17-26. Gerhardt, P. (1981). Manual of Methods for General Bacteriology. Washington, DC: American Society for Microbiology.

Groth, I., Schumann, P., Weiss, N., Martin, K. \& Rainey, F. A. (1996). Agrococcus jenensis gen. nov., sp. nov., a new genus of actinomycetes with diaminobutyric acid in the cell wall. Int J Syst Bacteriol 46, 234-239.

Hanson, R. S. \& Hanson, T. E. (1996). Methanotrophic bacteria. Microbiol Rev 60, 439-471.

Hanson, R. S., Netrusov, A. I. \& Tsuji, K. (1991). The obligate methanotrophic bacteria Methylococcus, Methylomonas, and Methylosinus. In The Prokaryotes, pp. 2350-2365. Edited by A. Balows, H. G. Trüper, M. Dworkin, W. Harder \& K. H. Schleifer. New York: Springer.

Henckel, T., Friedrich, M. \& Conrad, R. (1999). Molecular analyses of the methane-oxidizing microbial community in rice field soil by targeting the genes of the $16 \mathrm{~S}$ rRNA, particulate methane monooxygenase, and methanol dehydrogenase. Appl Environ Microbiol 65, 1980-1990.

Henckel, T., Jäckel, U., Schnell, S. \& Conrad, R. (2000). Molecular analyses of novel methanotrophic communities in forest soil that oxidize atmospheric methane. Appl Environ Microbiol 66, 1801-1808.

Holmes, A. J., Costello, A., Lidstrom, M. E. \& Murrell, J. C. (1995). Evidence that particulate methane monooxygenase and ammonium monooxygenase may be evolutionarily related. FEMS Microbiol Lett 132, 203-208.

Kämpfer, P. \& Kroppenstedt, R. M. (1996). Numerical analysis of fatty acid patterns of coryneform bacteria and related taxa. Can J Microbiol 42, 989-1005.

Luft, J. H. (1964). Electron microscopy of cell extraneous coats as revealed by ruthenium red staining. J Cell Biol 23, 54A-55A. 
Martin, K., Schumann, P., Rainey, F. A., Schuetze, B. \& Groth, I. (1997). Janibacter limosus gen. nov., sp. nov., a new actinomycete with meso-diaminopimelic acid in the cell wall. Int J Syst Bacteriol 47, 529-534.

Morton, J. D., Hayes, K. F. \& Semrau, J. D. (2000). Effect of copper speciation on whole-cell soluble methane monooxygenase activity in Methylosinus trichosporium OB3b. Appl Environ Microbiol 66, 1730-1733.

Murrell, J. C., McDonald, I. R. \& Bourne, D. G. (1998). Molecular methods for the study of methanotroph ecology. FEMS Microbiol Ecol 27, 103-114.

Phelps, P. A., Agarwal, S. K., Speitel, G. E., Jr \& Georgeou, E. (1992). Methylosinus trichosporium OB3b mutants having constitutive expression of soluble methane monooxygenase in the presence of high levels of copper. Appl Environ Microbiol 58, 3701-3708.

Stackebrandt, E. \& Goebel, B. M. (1994). Taxonomic note: a place for DNA-DNA reassociation and 16S rRNA sequence analysis in the present species definition in bacteriology. Int J Syst Bacteriol 44, 846-849.
Strunk, O. \& Ludwig, W. (1996). ARB: a software environment for sequence data. Munich: Technische Universität München. http://www.arb-home.de/

Takeda, K. (1988). Characteristics of a nitrogen-fixing methanotroph, Methylocystis T-1. Antonie van Leeuwenhoek 54, 521-534.

Trotsenko, Y. A. \& Khmelenina, V. N. (2002). Biology of extremophilic and extremotolerant methanotrophs. Arch Microbiol 177, 123-131.

Wang, F. L. \& Bettany, J. R. (1997). Methane emission from Canadian prairie and forest soils under short-term flooding conditions. Nutr Cycl Agroecosyst 49, 197-202.

Wayne, L. G., Brenner, D. J., Colwell, R. R. \& 9 other authors (1987). International Committee on Systematic Bacteriology. Report of the ad hoc committee on reconciliation of approaches to bacterial systematics. Int J Syst Bacteriol 37, 463-464.

Yavitt, J. B., Downey, D. M., Lang, G. E. \& Sexstone, A. J. (1990). Methane consumption in two temperate forest soils. Biogeochemistry 9, 39-52. 